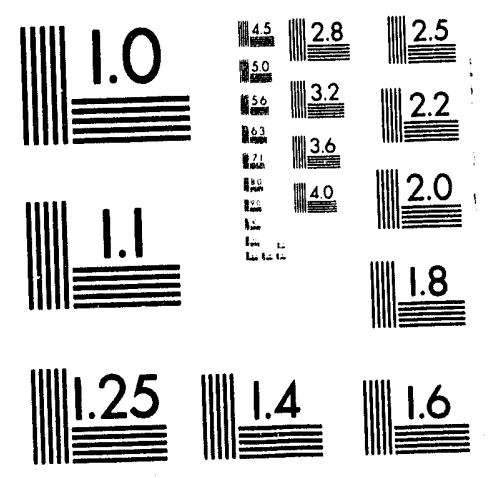



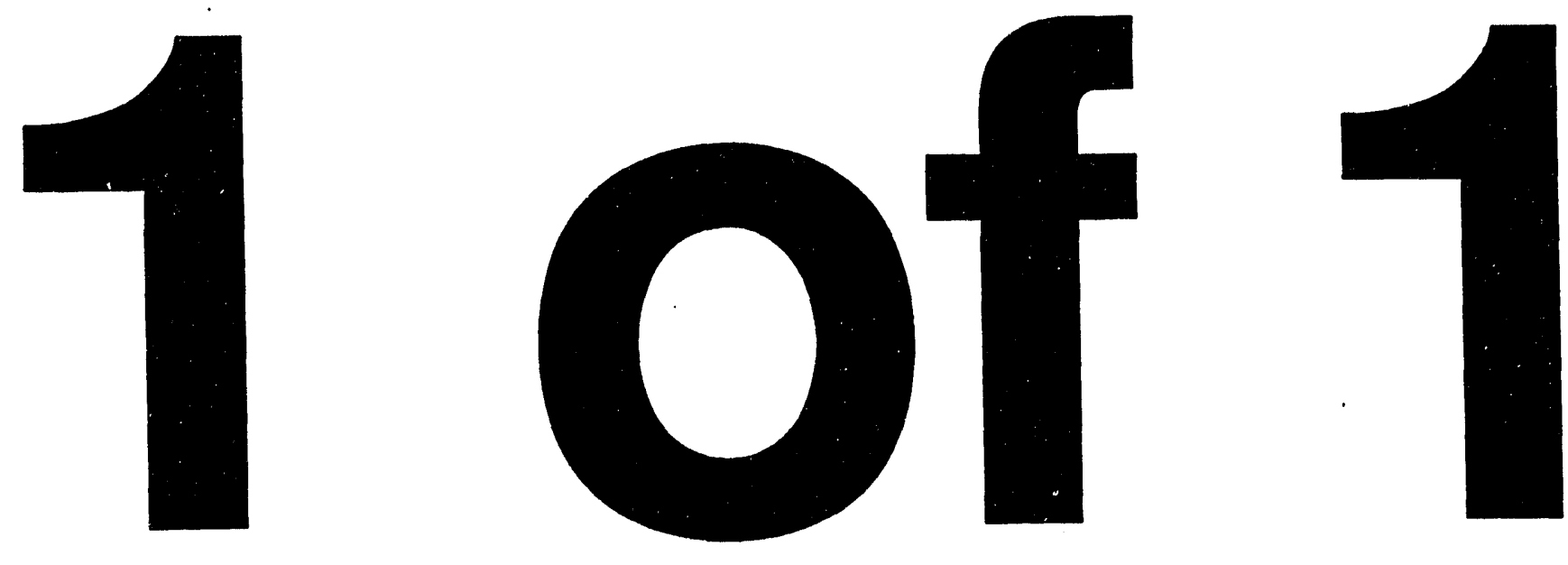
194958

PREPARED FOR THE U.S. DEPARTMENT OF ENERGY, UNDER CONTRACT DE-AC02-76-CHO-3073

PPPL-2962

UC-420,421,426

PPPL-2962

PERFORMANCE OF THE PBX-M PASSIVE PLATE STABILIZATION SYSTEM

H.W. KUGEL, R. BELL, S. BERNABEI, ET AL.

FEBRUARY, 1994

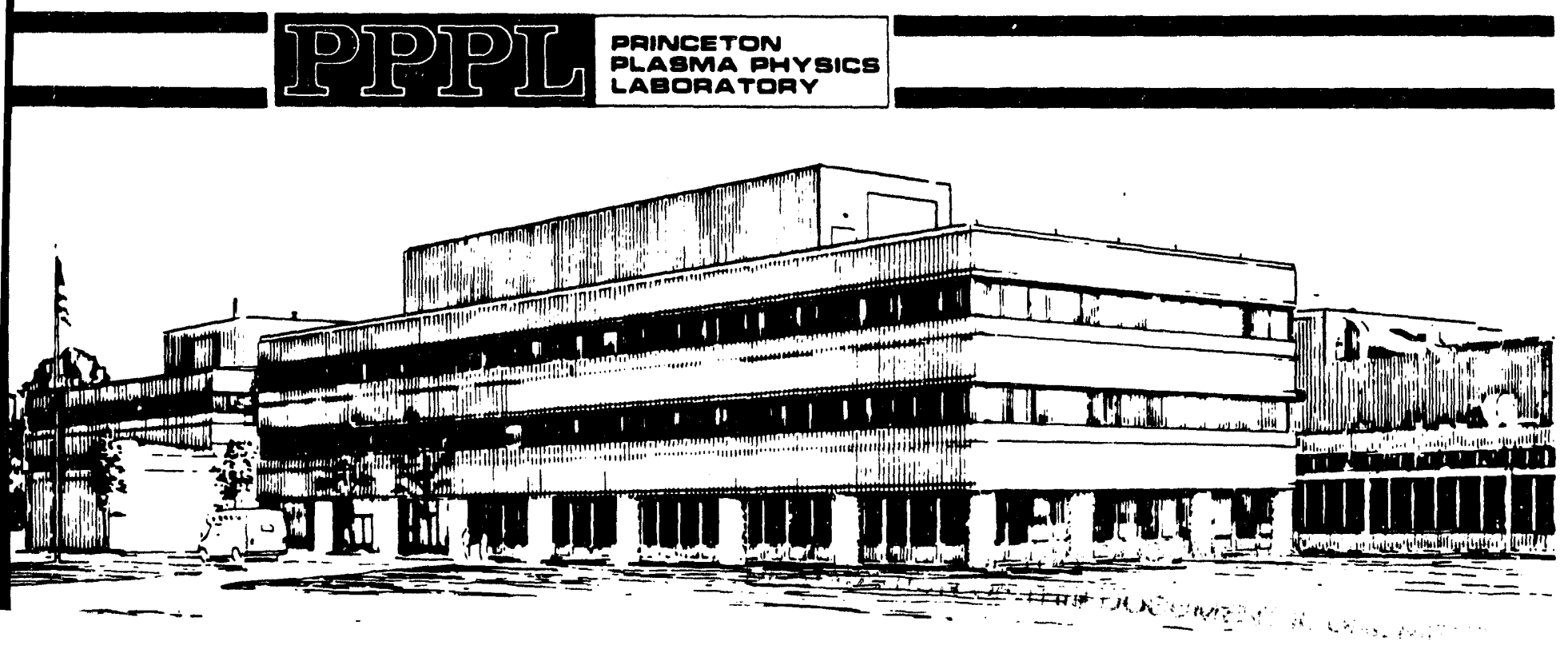




\section{NOTICE}

This report was prepared as an account of work sponsored by an agency of the United States Government. Neither the United States Government nor any agency thereof, nor any of their employees, makes any warranty, express or implied, or assumes any legal liability or responsibility for the accuracy, completeness, or usefulness of any information, apparatus, product, or process disclosed, or represents that its use would not infringe privately owned rights. Reference herein to any specific commercial produce, process, or service by trade name, trademark, manufacturer, or otherwise, does not necessarily constitute or imply its endorsement, recommendation, or favoring by the United States Government or any agency thereof. The views and opinions of authors expressed herein do not necessarily state or reflect those of the United States Government or any agency thereot.

\section{NOTICE}

This report has been reproduced from the best available copy.

Available in paper copy and microfiche.

Number of pages in this report: 7

DOE and DOE contractors can obtain copies of this report from:

Office of Scientific and Technical Information

P.O. Box 62

Oak Ridge, TN 37831;

(615) $576-8401$.

This report is publicly available from the:

National Technical Information Service

Department of Commerce

5285 Port Royal Road

Springfield, Virginia 22161

(703) $487-4650$ 


\title{
PERFORMANCE OF THE PBX-M PASSIVE PLATE STABILIZATION SYSTEM
}

\author{
H. W. Kugel, R. Bell, S. Bernabei, T. K. Chu, A. England ', G. Gettelfinger, \\ R. Hatcher, P. Heitzenroeder, R. Isler ${ }^{1}$, S. Jones ${ }^{3}$, R. Kaita, S. Kaye, B. LeBlanc, \\ M. Ono, M. Okabayshi, N. Sauthoff, L. Schmitz ${ }^{2}$, S. Sesnic, H. Takahashi, \\ W. Tighe, J. Timberlake, S. von Goeler, A. Post-Zwicker ${ }^{1}$, and the PBX-M Group. \\ Princeton Plasma Physics Laboratory, Princeton University, P.O. Box 451, Princeton, NJ 08543 \\ ${ }^{1}$ Oak Ridge National Laboratory, Oak Ridge, TN 37831 \\ 2Institute of Plasma and Fusion Research, UCLA, Los Angeles, CA 90024 \\ ${ }^{3}$ Massachusetts Institute of Technology, MA 02139
}

\begin{abstract}
The PBX-M passive plate stabilization system provides significant stabilization of long-wavelength external kink modes, the slowing of vertical instability growth rates, and the amelioration of disruption characteristics. The passive plate stabilization system has allowed the use of LHCD and IBW to induce current density and pressure profile modifications, and $m=1$ divertor biasing for modifying edge plasma transport. Improvements in the passive plate system insulators and support structures have provided reliable operation. Impurity influxes with the close-fitting passive plates are low. Solid target boronization is applied routinely to reduce conditioning time and maintain clean conditions.
\end{abstract}

\section{INTRODUCTION}

A strong cross-sectional indentation is applied to obtain bean-shaped plasmas for controlling magnetic curvature and shear. Active control of current and pressure profiles is performed using LHCD, pellet injection, IBW heating, and neutral beam injection. An electrically isolated, close-fitting, conducting, passive plate shell, with toroidal and poloidal gaps, surrounds over $70 \%$ of the plasma and provides stabilization of long-wavelength external kink modes, ameliorates disruption characteristics, and slows the growth rates of vertical instabilities. Feedback systems incorporating these features and possible synergies with the profile control techniques are under investigation as candidates for active control of disruption. PBX-M high- $\beta$ and profile modification experiments for accessing the near second stability regime have been discussed previously [13]. In this work, we review some aspects of the improved control, disruption, and operational characteristics that accrue from the passive plate stabilization system.

\section{SYSTEM DESCRIPTION}

Fig. 1 shows internal hardware details of the passive plates system, internal coils, poloidal limiters, and internal buses and insulating shields for passive plate biasing experiments. The passive plates stabilization system is comprised of 5 pairs of electrically isolated, single-turn plates, positioned above and below the magnetic axis. The plates consist of $2.5 \mathrm{~cm}$ thick aluminum (6061-T6) clad with a $0.3 \mathrm{~cm}$ thick layer of explosively bonded stainless steel (304-SS). The final configuration was achieved by bolting

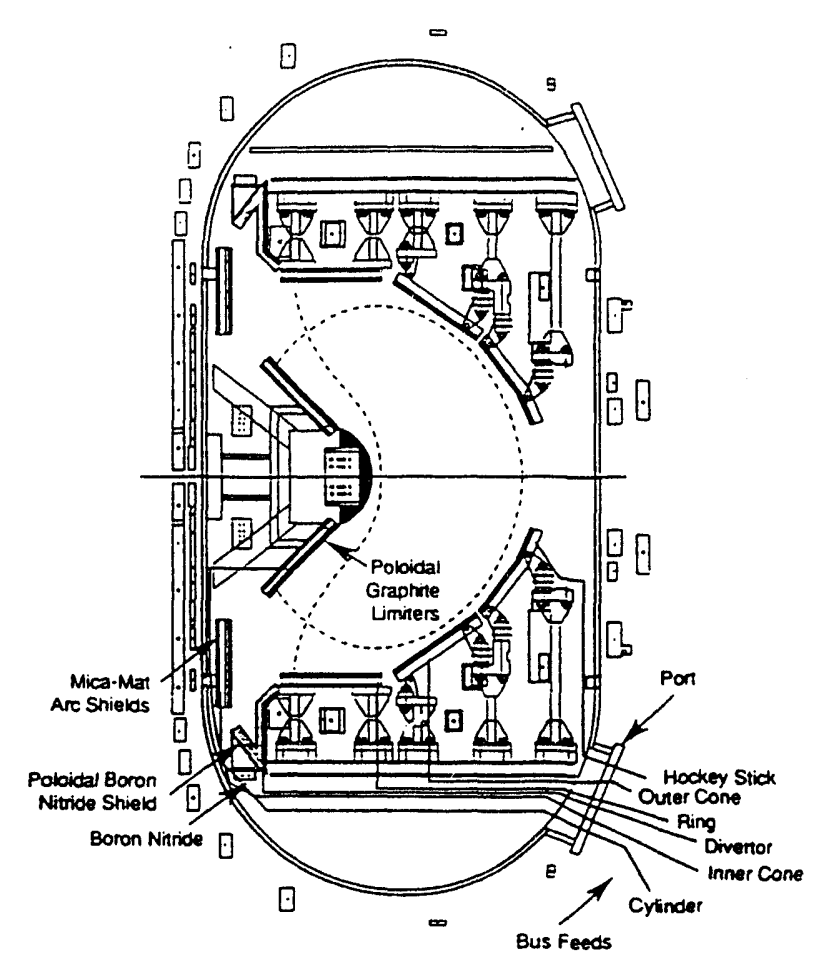

Fig.1 Partial schematic showing internal hardware.

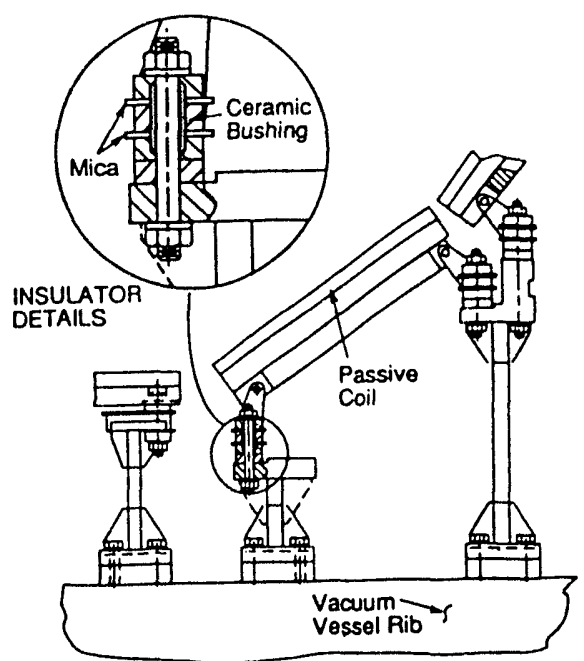

Fig. 2 Partial schematic showing details of passive plate support system.

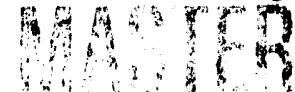




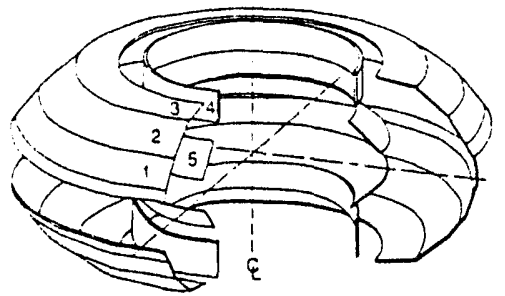

(a) Scnemalic view of PBX-M Passive Stabilizer

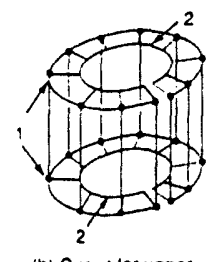

(b) Circunt lor upper No. 1 and 2

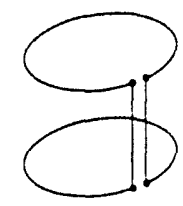

(c) Circuil lor piates No. 3.5

Fig.3 Schematic of passive plate elements and connections.

together 70 individual segments, each umall enough to pass through a vessel port. The bolted segments were fastened with nickel-plated splice plates. Insulated bridge plates provided mechanical continuity across toroidal gaps in each plate. Shown in Fig. 1 are the locations of the $2 \mathrm{~cm}$ high ATJ graphite poloidal limiters located on the passive plates at 12 toroidal locations. The passive plate system is designed to preclude interference with 17 interior water-cooled magnetic coils, 4 NBI ducts, 2 IBW heating antennas, 2 LHCD couplers, and various diagnostic assemblies.

Fig. 2 is a schematic diagram showing details of the support system and electrical insulators[4]. The electrical isolation requirements are achieved using over 400 ceramic alumina insulators together with about $42 \mathrm{~m}^{2}$ of mica sheet for associated shields. The five elements of the passive plate system (Fig.3a) are separated from each other with a poloidal gap, and each plate has a toroidal gap to provide the requisite $\mathrm{OH}$ electrical isolation. Fig. $3 \mathrm{~b}$ shows the present electrical connection of top and bottom plate pairs in a saddle coil arrangement. Plates of the two outer pairs (1-2), are connected to each other and also upper-to-lower. The upper-to-lower connection is accomplished by vertical nickel-plated aluminum buses at 11 locations. These connections facilitate the flow of eddy currents and reduce the effect of the $40 \mathrm{~cm}$ mid-plane gap required for auxiliary heating, and diagnostic access. The upper and lower plates of the three inner pairs are connected electrically via buses at one location (Fig.3b). The outer two pairs, designated "Hockey-Stick"(1) and "Outer-Cone"(2), act to stabilize primarily $n=1$ external kink modes. The three inner pairs , designated "Ring"(3), "Cylinder"(4), and "Inner-Cone"(5), perform stabilization of the $n=0$ vertical modes. The passive plate diagnostics are Rogowski coils on the vertical buses shown in Fig. $3 \mathrm{~b}$, and segmented loops embedded in the front surfaces of the plates. Other nearby in-vessel diagnostics include single-turn flux loops, thermocouples, divertor pressure gauges, and a diamagnetic loop. This in-vessel instrumentation requires about $2 \mathrm{~km}$ of interior instrumentation wiring with various types of electrical, thermal, and electromagnetic insulation.

\section{PLASMA PERFORMANCE}

The three inner pairs of passive plates (3-5), perform stabilization of the $n=0$ vertical modes. Previous work has shown that, with the vertical position feedback system disabled, the passive plates provided vertical stabilization to the plasma, for about $50 \mathrm{msec}$, before the plasma began moving vertically with an initial velocity of about $133 \mathrm{~cm} / \mathrm{s}[5,6]$. This ample duration of vertical stability allows the active feedback system to dampen vertical instabilities. Recent performance of this system is discussed elsewhere in this conference [7].
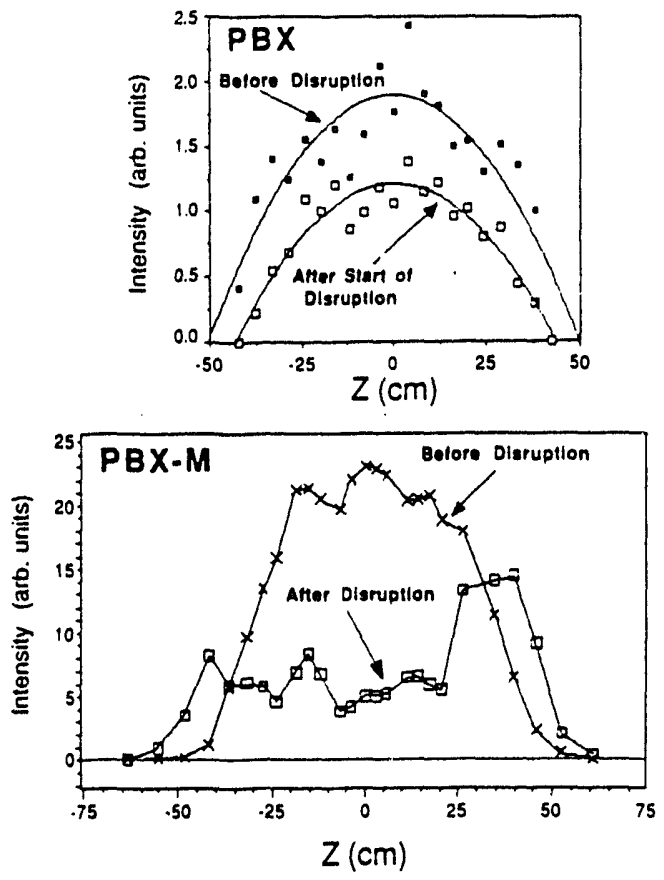

Fig. 4 The character of disruptions is different in PBX-M and PBX.

Fig.4 shows that the character of disruptions in PBX-M differs from that of the predecessor PBX which had more distant passive plates [1]. Chord-averaged soft $x$-ray (SXR) signals show that the collapse of the central region occurs across the entire profile to the edge in PBX, whereas in PBX-M, edge confinement is maintained for about 100 msec after the central collapse. This behavior implies that, due to the "tight-coupling" of the passive plates, internal processes, rather than external edge effects, are the primary cause of PBX-M disruptions[1].

Another effect of the passive plates can be seen in Fig. 5 which compares the PBX-M precursor duration times for indented, bean-shaped, "tightly-coupled" discharges with those for nearly circular, "loosely coupled" discharges. The significantly slower growth times for the "tightly-coupled" discharges may allow the use of active disruption avoidance control [8]. Plasma current decay rates following disruption depend on profile shape [9].

Lower Hybrid Current Drive (LHCD) has been applied to significantly modify PBX-M current density profiles in the presence of the closely-coupled passive plate stabilization system [3]. LHCD of frequency $4.6 \mathrm{GHz}$ and powers up to $600 \mathrm{~kW}$ has been applied with a fast response 


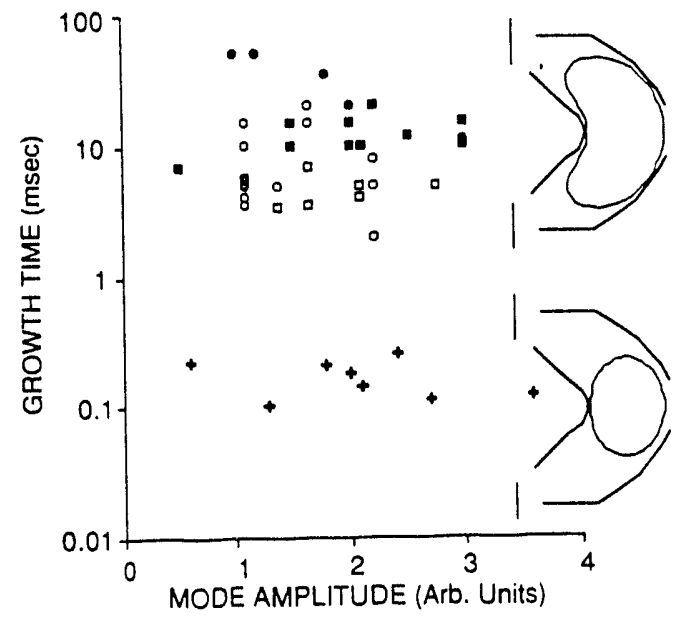

Fig. 5 Disruption precursor times are longer for close-coupling (top) and shorter for loose-coupling (bottom).

phase shifter which adjusts the phase of the launched wave during the discharge. A total power of $2 \mathrm{MW}$ is planned using the 2 launchers each coupled to 32 wave guides. Fig. 6 shows the time evolution of the hard x-ray intensity for an indented plasma with LHCD and NBI along a vertical cord through the magnetic axis. The emission profile became hollow and the $q=1$ profile decreased with the application of LHCD $[3,10]$.

Ion Bernstein wave heating (IBW) has been applied to significantly modify PBX-M pressure profiles and provided localized bulk ion heating in the presence of the closely-coupled passive plate stabilization system $[3,11]$. The 2 MW IBW system with operating frequencies in the range from 40 to $80 \mathrm{MHz}$ uses two antennae. Fig. 7 shows peaked density profiles with IBW for shaped plasmas. It is seen that in strongly heated, bean-shaped discharges, a peaked density profile evolves during the late phase of IBW injection from a flat $\mathrm{H}$-mode-like density profile[3, 11].

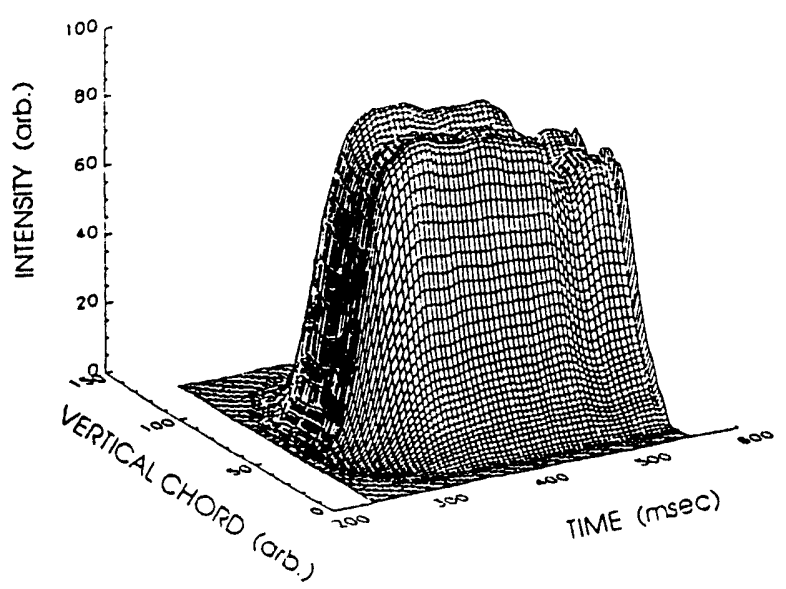

Fig. 6 Time evolution of the intensity of hard $x$-rays along a vertical cord during applied LHCD.

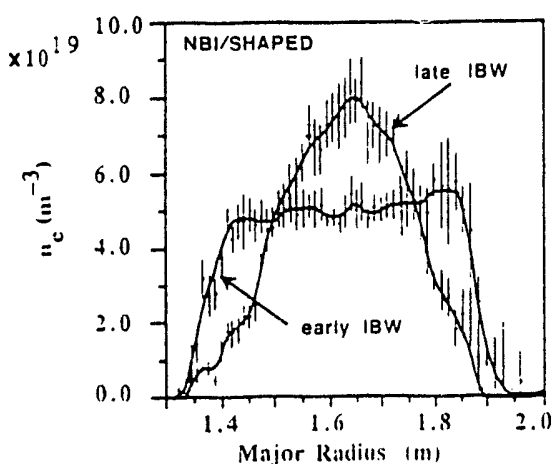

Fig.7 Peaked density profiles with IBW.

Edge plasma transport was modified using divertor biasing $[3,14]$. Preliminary, $m=1$ divertor biasing experiments have been applied to PBX-M using the passive plate buses shown in Fig.3. Bias voltages $-75 \mathrm{~V} \leq \mathrm{V}_{\mathrm{b}} \leq 75$ $\mathrm{V}$ were applied to the Inner Cone (2) and Ring (3) passive plate elements and bias currents of $-300 \mathrm{~A}<\mathrm{I}_{\mathrm{b}}<200 \mathrm{~A}$ were observed. Fig. 8 shows the NBI power required to achieve $\mathrm{H}$-modes was lowered $25 \%$ with the application of edge biasing voltages $>25 \mathrm{~V}$. Biasing experiments at higher voltages and currents, and other configurations are planned to make use of the versatility offered by the passive plate system.

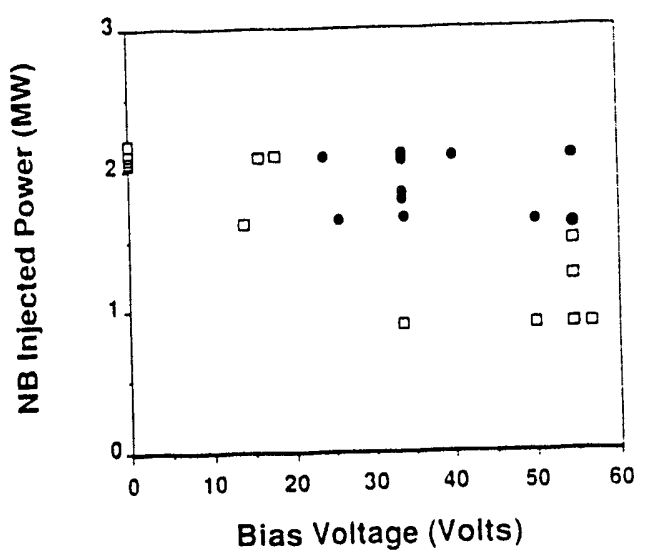

Fig. 8 Initial $m=1$ divertor biasing lowered $H$-mode NBI power threshold by $25 \%$. The solid symbols correspond to H-mode discharges; open symbols correspond to L-mode discharges.

\section{OPERATING PERFORMANCE}

Damage occurred in 1988 during the initial testing of the passive plate system, and was attributed to the singlepoint grounding of each individual plate to the vacuum vessel, the use of organic insulators in some locations, and arcing between support structures along toroidal field lines [4]. High power operations with the present configuration, described previously [4], have not encountered these difficulties.

Initially, single-point grounding of each passive plate was employed [4]. This allowed the halo plasma to form closed circuit paths for large current flows through the 

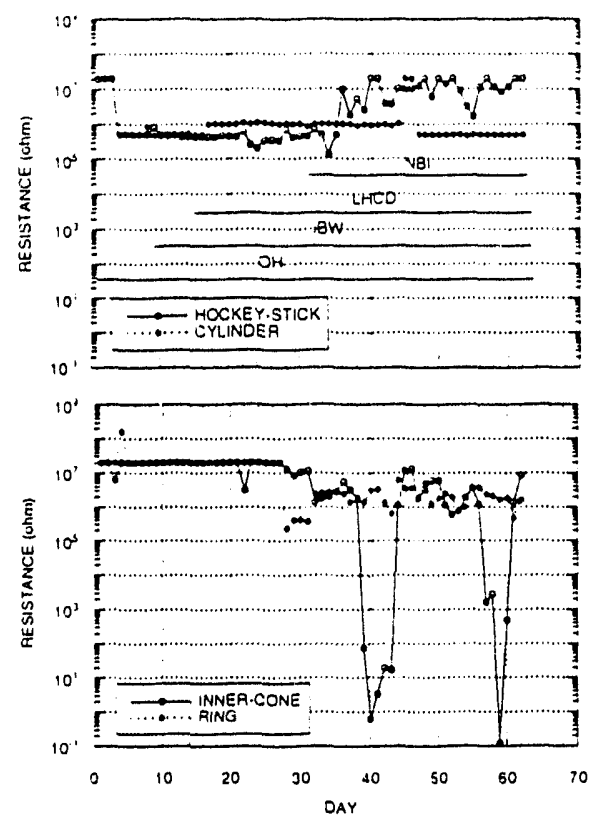

Fig.9 Passive plate resistance to vessel-ground varies. Impurity deposition during high power operation lowers the resistance of divertor region insulators.

supports and the vessel. These currents caused severe damage to mechanical supports. This effect was eliminated to date by connecting each passive plate element to vesselground through an external, $500 \Omega$ carbon resistor. This limits current flows, and maintains plate potential relative to vessel-ground.

The previous use of organic (polymide) insulators in some locations resulted in nitrogen pressure bursts during operations [4]. These pressure bursts are believed to be the result of arcing across the organic insulators during transients which would char the surface and irreversibly damaged the organic insulators. This was eliminated by replacing all organic insulators with alumina insulators and eliminating all direct-line-of-sight arc paths.

Arcing along toroidal flux lines, between support structures nominally at the same potential, was greatly reduced using shields fabricated from mica-mat [4]. Some discoloration from such arcing still is observed at some locations, but the residual arcing has not been sufficient to cause significant damage, out-gassing, or other operation difficulties.

Prior to daily operations, the $500 \Omega$ drain resistors are disconnected, and the resistance between each passive plate and vessel-ground is measured in both polarity directions. The electrical isolation of the passive plates, as measured with a standard $9 \mathrm{v}$ ohmmeter, are found to undergo daily variations. Fig. 9 shows typical results of these daily measurements. The largest changes occur during high power operation for passive plates located in the divertor region. This may be due to the preferential power and impurity depositions received by these passive plates from the strike points and disruptions [9]. Higher voltage resistance measurements to help identify the nature of these conducting paths have been avoided so as not to introduce possibly irreversible breakdown damage.

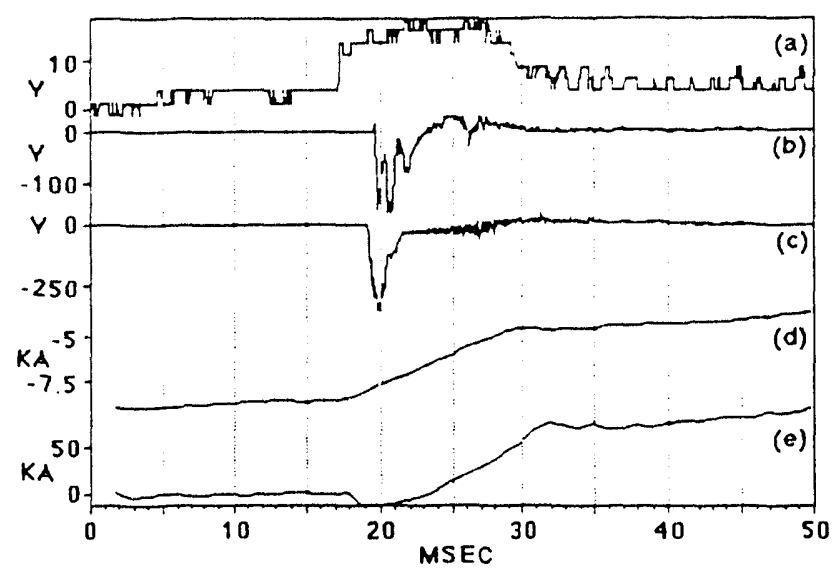

Fig.10 Passive plate voltage waveforms at startup of $400 \mathrm{kA}$ discharge for (a) passive plate No.5 toroidal gap, (b) the poloidal gap between plates No.2 and No.3, (c) an outer poloidal limiter relative to plate No.1, (d) ohmic current and (e) plasma current

However, after several vessel vents, these conducting and sometimes semiconducting paths undergo chemical changes and become insulating. This behavior suggests that these impurity films could not support large current flows between the plasma and vessel-ground. The presence of these films during operations has not produced any degradation in performance.

The initial measurements found that the largest induced voltages were observed at plasma startup and at plasma current disruption and exhibited characteristics depending on the operating conditions. Fig. 10 and 11 show typical passive plate waveforms at startup and disruption, respectively. The highest voltages observed have been at disruption and were less than $2 \mathrm{kV}$ [12].

The issue of the proximity of the edge plasma to the passive plate surface, the resultant impurity influxes, and consequent radiation were early concerns. The radiated power was highest at the edge and only mildly peaked on the plasma center in highly indented, high- $\beta_{t}$ discharges, with the plasma closest to the plates [14]. Typical central plasma

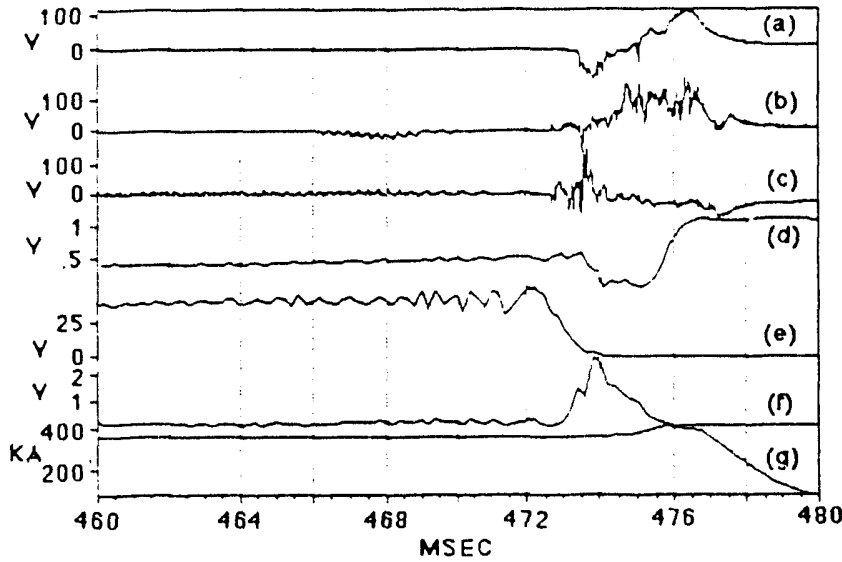

Fig. 11 Passive plate voltage waveforms at disruption for a $400 \mathrm{kA}$ discharge for (a) passive plate No. 5 toroidal gap, (b) passive plate No.2-No.3 poloidal gap, (c) an outer poloidal limiter relative to passive plate No.1, (d) a segmented flux lop difference, (e) a central soft $x$-ray detector, (f) an outer soft $x$-ray detector, and (g) the plasma current. 

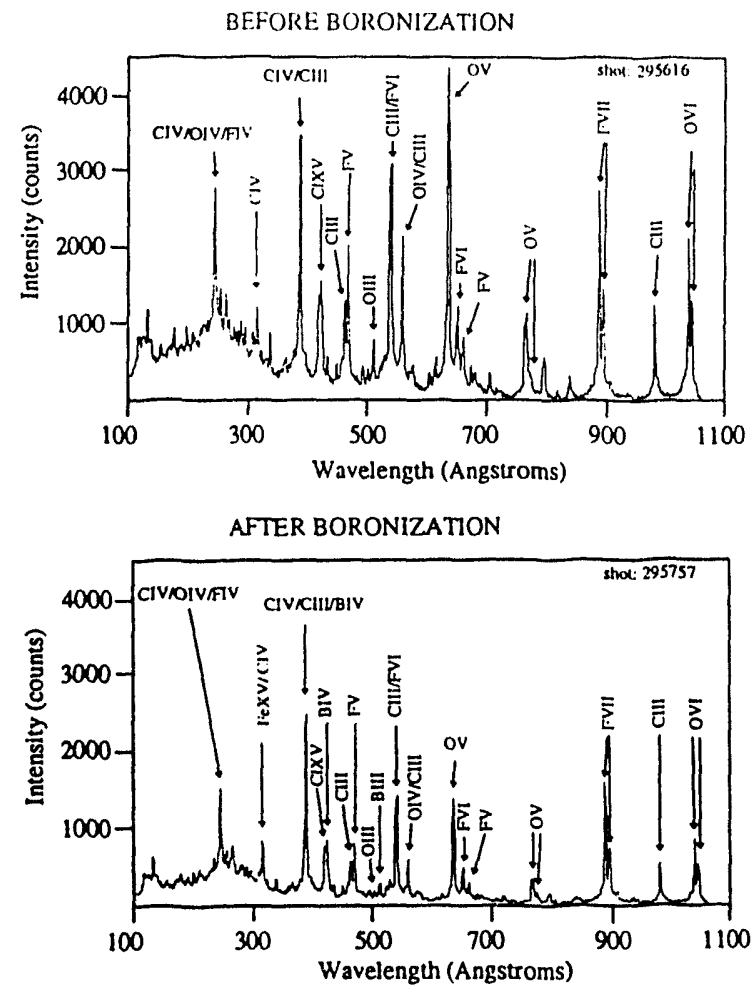

Fig. 12 U.V. spectral intensities before and after boronization.

radiated power densities were $\sim 0.1 \mathrm{~W} / \mathrm{cm}^{3}$ with $<0.5$ $\mathrm{W} / \mathrm{cm}^{3}$ at the edge and total radiated powers of $15 \%$. In these discharges, the electron energy balance was dominated by electron and ion conduction with only minor contributions from radiation [13].

These results were achieved without boronization. In an effort to shorten conditioning time when recovering from vessel vents, and when approaching new regimes, and to maintain clean vessel conditions, solid target boronization (STB) is being applied routinely [15]. Fig. 12 shows U.V. spectral intensities for two fiducial discharges (a) before first boronization, and (b) after first boronization. Strong edge plasma spectral lines from low- $\mathrm{Z}$ elements decreased. Fe intensities rose during neutral beam injection due to hotter edge conditions[15]. Typical boronization, require about 1 to 2 hours per application, and several applications per week have been applied, depending on the experimental requirements. Studies of the boron deposition thickness, erosion, toroidal and poloidal distributions on the passive plates following boronization are in progress.

\section{CONCLUSION}

The passive plate system is being used successfully to provide stabilization of long-wavelength external kink modes, to slow the growth of vertical instabilities, and to ameliorate disruption characteristics. The passive plate stabilization system has allowed the use of LHCD and IBW for current density and pressure profile modification and $\mathrm{m}=1$ divertor biasing for modification of edge plasma transport. Future plans include characterizing new operating regimes using these tools, pursuing possible synergies involving profile control techniques, and investigating features leading to active control of instabilities.

\section{ACKNOWLEDGMENT}

We wish to acknowledge the helpful contributions of L. Gereg, J. Semler, E. Thorsland and the PBX-M Technical Staff. This work was supported by US Department of Energy Contract No. DE-AC02-76CHO3073.

\section{REFERENCES}

[1] R. E. Bell, et al., "Control of Plasma Shape and Performance of the PBX-M Tokamak Experiment in High- $\beta_{t} /$ High- $\beta_{\mathrm{p}}$ Regimes", Phys. Fluids, B2(6), 1271 (1990).

[2] R. Kaita et al., " Current and Pressure Profile Modification Experiments with Lower Hybrid Current Drive and Ion Bernstein Wave Heating in PBX-M", in Proceedings of the 14th International Conference on Plasma Physics and Controlled Nuclear Fusion Research, IAEA-CN-56/H-1-2, Wurzburg, Germany, 30 September - 7 October 1992, IAEA, Vienna.

[3] S. Bernabei, et al., "Experimental Exploration of Profile Control in the Princeton Beta Experiment-Modified (PBX-M) Tokamak", Phys. Fluids, B5(7) 2562 (1993).

[4] P. Heitzenroeder, et al., "PBX-M Passive Coil System Reliability Improvements", in Proceedings of IEEE Thirteenth Symposium on Fusion Engineering, p 348, Knoxville. Tn, 2-6 October 1989.

[5] R. E. Hatcher, S. Jardin, P. Mathe, M. Okabayashi, M. Reuch, "Vertical Position Feedback System for PBX-M", in Proceedings of IEEE Thirteenth Symposium on Fusion Engineering, p 463 Knoxville. Tn, 2-6 October 1989.

[6] R. E. Bell et al., "Performance of the Plasma Shaping Control System on the PBX-M Tokamak", in Proceedings of IEEE Thirteenth Symposium on Fusion Engineering, p 467, Knoxville. Tn, 2-6 October 1989.

[7] R. E. Hatcher et al., "PBX-M Vertical Position Control Using Passive Shell Control", (to be published).

[8] M. Okabayashi, et al., "Avoidance and Control of Disruptions in the PBX-M Tokamak", in "Proceedings of the IAEA Technical Committee Meeting on Avoidance and Control of Tokamak Disruptions", Culham, 10-12 September 1991.

[9] S. F. Paul, S. C. Jardin, H. W. Kugel, and M. Okabayashi, "Interactions Between the Plasma and the Stabilizing Shell During Disruptions in PBX-M", J. Nucl. Mater., 176-177, 197 (1990).

[10] R. E. Bell et al., "Control of the Current Density Profile with Lower Hybrid Current Drive on PBX-M", in the Proceedings of the Tenth Topical Conference on Radio Frequency Power in Plasmas, 1-3 April 1993, Boston, MA.

[11] M. One, et al., "PBX-M Ion Berstein Wave Heating Overview", in the Proceedings of the Tenth Topical Conference on Radio Frequency Power in Plasmas, 1-3 April 1993, Boston, MA.

[12] H. W. Kugel, M. Okabayashi, and S. Schweitzer, "Diagnostic Method for Measuring Voltages Induced in the PBX-M Stabilizing Shell", Rev. Sci. Instrumen., 61 (10), 3295 (1990).

[13] S. F. Paul, R. J. Fonck, R. C. Isler, and S. Sesnic, "Impurity Behavior in High- $\beta$ Plasmas in PBX-M", J. Nucl. Mater. 196-198, 503 (1992).

[14] L. Schmitz, et al., "M=1 Divertor Biasing Experiments in PBX-M", in Proceedings of IAEA Technical Committee Meeting on Tokamak Biasing, p.285, 8-10 September, 1992, Montreal, Canada.

[15] H. W. Kugel et al., "Initial Boronization of PBX-M Using Ablation of Solid Boronized Probes", Princeton Plasma Physics Laboratory Report, No. PPPL-2903, May 1993. 


\section{EXTERNAL DISTRIBUTION IN ADDITION TO UC-420}

Dr. F. Paoloni, Univ, of Wollongong, AUSTRALIA

Prof. M.H. Brennan, Univ. of Sydney, AUSTRALIA

Plasma Research Lab., Australian Nat. Univ., AUSTRALIA

Prof. I.A. Jones, Flinders Univ, AUSTRALIA

Prof. F. Cap, Inst. for Theoretical Physics, AUSTRIA

Prof. M. Heindler, Institut für Theoretische Physik, AUSTRIA

Prof. M. Goossens, Astronomisch Instituut, BELGIUM

Ecole Royale Militaire, Lab. de Phy. Plasmas, BELGIUM

Commission-European, DG. XII-Fusion Prog., BELGIUM

Prof. R. Bouciqué, Rijksuniversiteit Gent, BELGIUM

Dr. P.H. Sakanaka, Instituto Fisica, BRAZIL

Prof. Dr. I.C. Nascimento, Instituto Fisica, Sao Paulo, BRAZIL Instituto Nacional De Pesquisas Espaciais-INPE, BRAZIL Documents Otfice, Alomic Energy of Canada Ltd., CANADA Ms. M. Morin, CCFMTokamak de Varennes, CANADA

Dr. M.P. Bachynski, MPB Technologies, Inc., CANADA

Dr. H.M. Skarsgard, Univ. of Saskatchewan, CANADA

Prof. J. Teichmann, Univ. of Montreal, CANADA

Prof. S.R. Sreenivasan, Univ. of Calgary, CANADA

Prof. T.W. Johnston, INRS-Energie, CANADA

Dr. R. Bolton, Centre canadien de fusion magnétique, CANADA

Dr. C.R. James, Univ. of Alberta, CANADA

Dr. P. Lukác, Komenského Universzita, CZECHO-SLOVAKIA

The Librarian, Culham Laboratory, ENGLAND

Library, R61, Rutherford Appleton Laboratory, ENGLAND

Mrs. S.A. Hutchinson, JET Library, ENGLAND

Dr. S.C. Sharma, Univ. of South Pacific, FIJI ISLANDS

P. Mähönen, Univ. of Helsinki, FINLAND

Prot. M.N. Bussac, Ecole Polytechnique, FRANCE

C. Mouttet, Lab. de Physique des Milieux lonisés, FRANCE

J. Radet, CEN/CADARACHE - Bat 506, FRANCE

Prof. E. Economou, Univ. of Crete, GREECE

Ms. C. Rinni, Univ. of loannina, GREECE

Preprint Libray, Hungarian Academy of Sa., HUNGARY

Dr. B. DasGupta, Saha Inst. of Nuclear Physics, INDIA

Dr. P. Kaw, Inst. for Plasma Research, INDIA

Dr. P. Rosenau, Israel Inst. of Technology, ISRAEL Librarian, Intemational Center for Theo Physics, ITALY

Miss C. De Palo, Associazione EURATOM-ENEA, ITALY

Dr. G. Grosso, Istituto di Fisica del Plasma, ITALY

Prof. G. Rostangni, Istituto Gas lonizzati Del Cnr, ITALY
Dr. H. Yamato, Toshiba Res \& Devel Center, JAPAN

Prof. I. Kawakami, Hiroshima Univ., JAPAN

Prof. K. Nishikawa, Hiroshima Univ., JAPAN

Librarian, Naka Fusion Research Establishment, JAERI, JAPAN

Director, Japan Atomic Energy Research Inst., JAPAN

Prof. S. Itoh, Kyushu Univ., JAPAN

Research Info. Ctr., National Instit. for Fusion Science, JAPAN

Prof. S. Tanaka, Kyoto Univ., JAPAN

Library, Kyoto Univ., JAPAN

Prof. N. Inove, Univ. of Tokyo, JAPAN

Secretary, Plasma Section, Electrolectinical Lab., JAPAN

S. Mori, Technical Advisor, JAERI, JAPAN

Dr. O. Mitarai, Kumamoto Inst. of Technology, JAPAN

Dr. G.S. Lee, Korea Basic Sci. Ctr., KOREA

J. Hyeon-Sook, Korea Atomic Energy Research Inst., KOREA

D.I. Choi, The Korea Adv. Inst. of Sci. \& Tech., KOREA

Prof. B.S. Liley, Univ. of Waikato, NEW ZEALAND Inst of Physics, Chinese Acad Ssi PEOPLE'S REP. OF CHINA Library, Inst. of Plasma Physics, PEOPLE'S REP. OF CHINA Tsinghua Univ. Library, PEOPLE'S REPUBLIC OF CHINA Z. Li, S.W. Inst Physics, PEOPLE'S REPUBLIC OF CHINA Prot. J.A.C. Cabral, Instituto Superior Tecnico, PORTUGAL Prof. M.A. Hellberg, Univ. of Natal, S. AFRICA

Prof. D.E. Kim, Pohang Inst. of Sci. \& Tech., SO. KOREA

Prof. C.I.E.M.A.T, Fusion Division Library, SPAIN

Dr. L. Stenflo, Univ. of UMEA, SWEDEN

Library, Royal Inst. of Technology, SWEDEN

Prof. H. Wilhelmson, Chalmers Univ. of Tech., SWEDEN Centre Phys. Des Plasmas, Ecole Polytech, SWITZERLAND Bibliotheek, Inst. Voor Plasma-Fysica, THE NETHERLANDS Asst. Prot. Dr. S. Cakir, Middle East Tech. Univ., TURKEY Dr. V.A. Glukhikh,Sci. Res. Inst. Electrophys.I Apparatus, USSR

Dr. D.D. Ryutov, Siberian Branch of Academy of Sci., USSR

Dr. G.A. Eliseev, I.V. Kurchatov Inst., USSR

Librarian, The Ukr.SSR Academy of Sciences, USSR

Dr. L.M. Kovrizhnykh, Inst. of General Physics, USSR Kernforschungsanlage GmbH, Zentralbibliothek, W. GERMANY Bibliothek, Inst. Für Plasmatorschung, W. GERMANY Prof. K. Schindler, Ruhr-Universitát Bochum, W. GERMANY Dr. F. Wagner, (ASDEX), Max-Planck-Institut, W. GERMANY Librarian, Max-Planck-Institut, W. GERMANY 

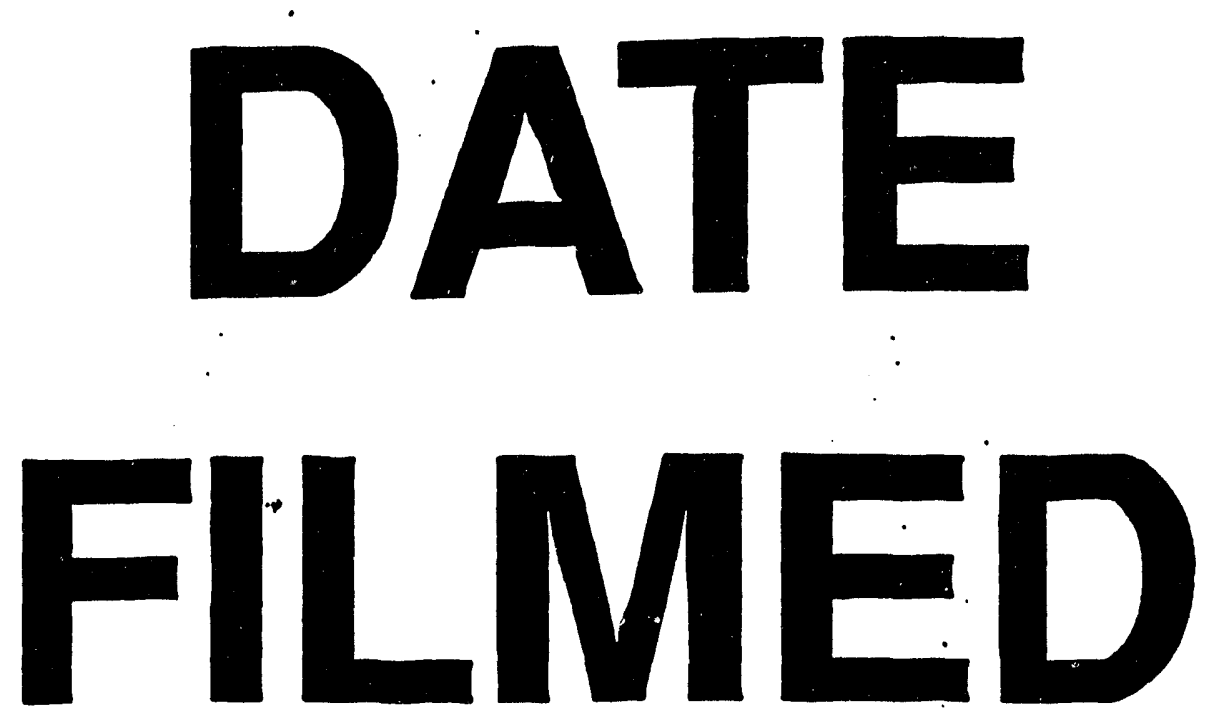

$3 / 23 / 94$
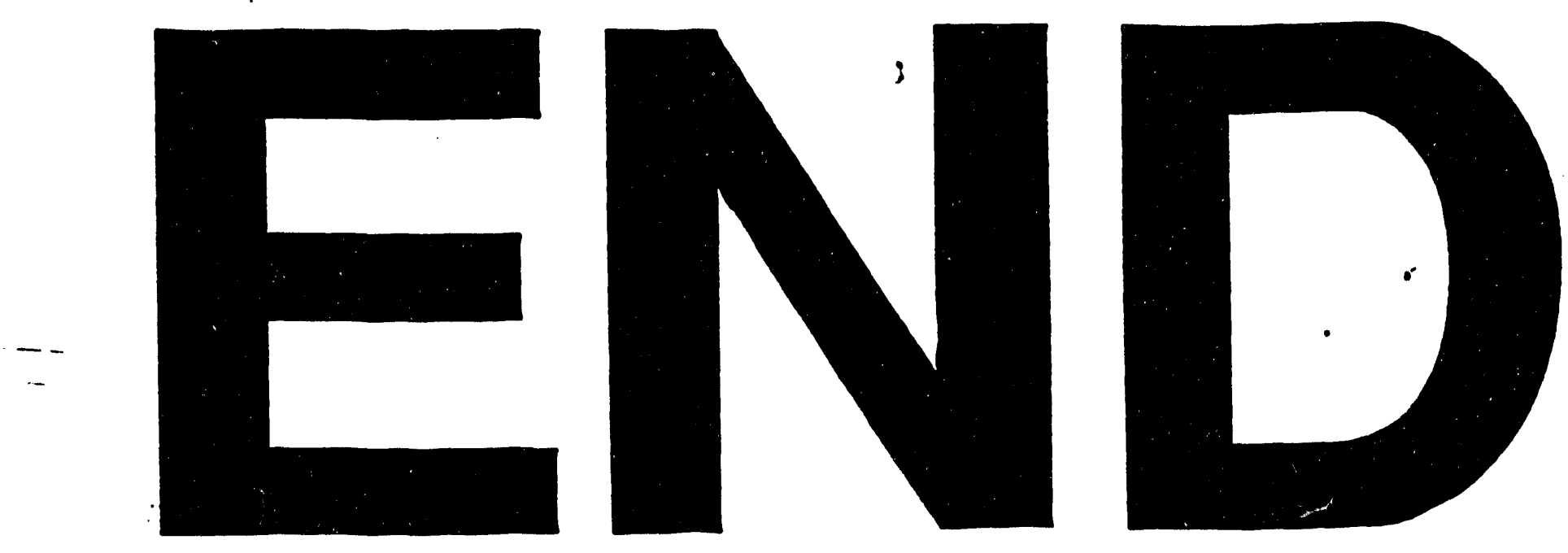
